\title{
The continuation from near to far field at low frequencies
}

\section{Kleinman, $\mathbf{R}$}

Published in:

Antennas and Propagation Society International Symposium

Publication date:

1966

Document Version

Publisher's PDF, also known as Version of record

Link back to DTU Orbit

Citation (APA):

Kleinman, R. (1966). The continuation from near to far field at low frequencies. In Antennas and Propagation Society International Symposium (Vol. Volume 4, pp. 474-475). IEEE.

\section{General rights}

Copyright and moral rights for the publications made accessible in the public portal are retained by the authors and/or other copyright owners and it is a condition of accessing publications that users recognise and abide by the legal requirements associated with these rights.

- Users may download and print one copy of any publication from the public portal for the purpose of private study or research.

- You may not further distribute the material or use it for any profit-making activity or commercial gain

- You may freely distribute the URL identifying the publication in the public portal

If you believe that this document breaches copyright please contact us providing details, and we will remove access to the work immediately and investigate your claim 
The Continuation Irom Necr to Par Fiela at Low Frequencies-

\author{
R.E. Kleinman
}

Laboratory of Electromagnetio Theory * Technical Jniversity of Denmark

in explicit formula is derived expressing the low frequency expansion of the far field coefficient for any radiating or scattered electromagnetic field in terms of the low frequency expansion of the near field. It is shown that a knowledge of a given number of near field terms suffices to determine the same number of far field terms, thus disproving the previously held contention that $p+I$ near field terms were needed to determine $p$ far field terms. Lord Rayleigh provided a ineans for continuing the first term in the low frequency expansion of the near field into the far field (Philos.Mag., XLIV, 28 - 52, 1897) and A.F. Stevenson generalized Fayleigh's continuation procedure to include higher order terms (J.Appl.Phys., 24, 1134 - 1142, 1953). This method involves expending the rear field terms in spherical harmonics and matching the coefficients with near field representations of spherical Hankel functions. Since this is not necessarily ${ }^{a}$ trivial calculation, unless the near field terms are already in this form, this procedure is not completely satisfying.

The most natural approach to the continuation problem makes use of the vector analogue of the Helmholtz integral representation of a field in terms of its values on a surface, where the surface field is expressed as a low frequency expansion. However, as observed by Stevenson, "the disedvantage of this procedure is that it is then found that to obtain even the first term in the series in the wave zone ( $f a x$ field) it is necessary to know two terms in the series for the surface field and generally to obtain $p$ terms in the wave zone we must know $p+1$ terms in the surfece field. We thus lose accuracy in carrying through this procedure".

The present work shows how this criticism may be removed and that it is possible to accomplish the continuation of the near field into the far field using the natural approach based on the vector analogue of Helmholtz' theorem without requiring expansions in spherical harmonics and without loss of accuracy. The method described

- in leave from the Radiation Laboratory, The University of Michigan 
here owes its success to an apparently little known vector identity and a particular choice of the form of the vector Belmholtz integral representaion. Though it must be possible to establish this result using any equivalent form of this representation, an unfortunate choice can make the required analysis prohibitively obscure, which apparently was the case in previous attempts.

Also included is a discussion of the first or Rayleigh term incfar field scattered by a perfect conductor illuminated by a plane wave. Using the representation described above, it is shown that this term may be decomposed into two parts, one proportional to the volume of the scatterer and one, in a sense, proportional to the elangation of the scatterer, i.e.the difference between the volume of the scatterer and the volume of the smallest sphere enclosing it. 